\title{
APLIKASI ALGORITMA DIFFERENTIAL EVOLUTION UNTUK DESAIN OPTIMAL LOAD FREQUENCY CONTROL PADA PEMBANGKIT LISTRIK TENAGA HIBRID ANGIN DAN DIESEL
}

\author{
Muhammad Ruswandi Djalal ${ }^{1}$, Machrus Ali ${ }^{2}$, Hidayatul Nurohmah ${ }^{3}$, Dwi Ajiatmo ${ }^{4}$ \\ ${ }^{1}$ Teknik Energi, Politeknik Negeri Ujung Pandang \\ 2,3,4 Teknik Elektro, Universitas Darul 'Ulum \\ Email: 1'wandi@poliupg.ac.id, machrus7@gmail.com, ${ }^{3}$ hidayatul_nurohmah@gmail.com, \\ ${ }^{4}$ dwiajiatmo@gmail.com
}

(Naskah masuk: 17 Agustus 2017, diterima untuk diterbitkan: 17 Oktober 2018)

\begin{abstract}
Abstrak
Perubahan frekuensi beban sangat mempengaruhi kualitas daya pada sumber energi terbarukan wind turbine yang hibrid dengan diesel. Sistem listrik tenaga gabungan (hybrid) terdiri dari beberapa pembangkit terbarukan seperti pembangkit tenaga angin, tenaga surya, tenaga air, dan lain-lain. Beberapa masalah yang bisa meningkatkan osilasi frekuensi rendah pada system, seperti setting gain dan konstanta waktu kecil dari Automatic Voltage Regulator yang tidak optimal, jalur transmisi yang panjang sehingga kemampuannya lemah (weak line). Pada beberapa penelitian sebelumnya, sistem wind-diesel dikontrol dengan pengendali konvensional Proportional, Integral, Derivative (PID), namun penyetelan nilai gain PID masih dalam metode trial-error, sehingga sulit untuk mendapatkan nilai PID yang optimal. Dalam penelitian ini diusulkan suatu metode optimasi parameter PID pada wind-diesel dengan menggunakan metode cerdas berbasis Differential Evolution (DEVO). Fungsi objective pada penelitian ini adalah meminimalkan Time Absolute Error (ITAE), sehingga overshoot akan diredam dengan baik. Pemodelan wind-diesel menggunakan diagram fungsi transfer dari wind-diesel. Dari hasil analisa didapatkan parameter PID optimal masing-masing, $\mathrm{Kp}=79.9999, \mathrm{Ki}=59.9998, \mathrm{Kd}=9.9006$. Overshoot terkecil yang dihasilkan adalah sebesar -7.932e-05 hingga 6.792e-10 pu di mana nilai overshoot terkecil dibandingkan dengan model kontroler yang lain. Respon frekuensi yang didapatkan penalaan PID yang optimal, akan meredam osilasi frekuensi akibat perubahan beban, ditunjukkan dengan overshoot yang kecil dan settling time yang cepat untuk menuju ke kondisi steady state.
\end{abstract}

Kata kunci : Wind-Diesel Power Plant, PID, DEVO, Frekuensi, Overshoot, Settling time

\section{APPLICATION OF DIFFERENTIAL EVOLUTION ALGORITHM FOR OPTIMAL DESIGN OF LOAD FREQUENCY CONTROL ON WIND AND DIESEL HIBRID POWER PLANT}

\begin{abstract}
Changes in load frequency greatly affect the power quality of renewable wind turbine energy sources with diesel. Hybrid power system is a network consisting of several renewable energy plants such as wind power, solar power, hydro power, and others. Some problems can increase the low frequency oscillations in the system, such as gain settings and small time constants of the non-optimal Automatic Voltage Regulator, long transmission lines so that their capabilities are weak (weak line). In some previous studies, the wind-diesel system is controlled by conventional Proportional, Integral, Derivative (PID) controllers, but the PID gain setting is still in the trial-error method, making it difficult to obtain optimal PID values. In this research, we proposed a method of optimizing PID parameters in wind-diesel by using intelligent method based on Differential Evolution (DEVO). The objective function of this research is to minimize Time Absolute Error (ITAE), so that the overshoot will be muted properly. Wind-diesel modeling uses the diagram of the transfer function of wind-diesel. From the analysis results obtained optimal PID parameters respectively, $K p=79.9999, K i=59.9998, K d=9.9006$. The smallest resulting overshoot is -7.932e-05 to 6.792e-10 pu where the smallest overshoot value is compared to other controller models. The frequency response obtained by optimal PID tuning will dampen the frequency oscillation due to load changes, indicated by small overshoot and fast settling time to steady state conditions.
\end{abstract}




\section{PENDAHULUAN}

Pembangkit listrik dengan sumber energi terbarukan semakin banyak digunakan. Beberapa pembangkit yang bersumber dari energy terbarukan seperti, tenaga matahari (solar cell), angin (wind turbine), air (micro hydro), dll. Untuk tenaga angin sendiri, penggunaannya sudah banyak digunakan sebagai sumber penggerak untuk generator. Pemanfaatan angin sebagai tenaga penggerak generator sangat bergantung pada kondisi angina pada daerah tersebut, sehingga diperlukan study yang signifikan. Oleh karena itu, pengoptimalan kinerja pada pembangkit tenaga angin ini dibutuhkan suatu pembangkit lain agar lebih maksimal dalam memberikan ketersediaan energy listrik, salah satunya dengan menggunakan pembangkit tenaga diesel. Pembangkit wind-diesel sangat baik dalam melakukan pelayanan ke konsumen, hal tersebut karena, system hybrid lebih baik disbanding dengan stand alone. Kualitas suplai tenaga yang ada pada sistem hibrid, akan berpengaruh karena adanya perbedaan pengaturan fluktuasi frekwensi

Pada beberapa penelitian sebelumnya, studi tentang pemanfaatan sistem pembangkit tenaga hibrid adalah membahas tentang pengontrolan frekuensi serta koordinasi hibrid sistem fuel cell untuk meningkatkan performance dari suatu sistem mikrogrid. Pengaturan dan sistem monitoring yang diusulkan pada penelitian adalah bagaimana mengontrol power quality, dan kestabilan frekuensi dengan adanya perubahan daya.

Studi sebelumnya telah membahas bagaimana pengaturan frekuensi beban pada tenaga anginadiesel, diantaranya, (BHA'ITI, AL-ADEMI, \& BANSAL; Bhatti, Al-Ademi, \& Bansal, 1997; Junrui, Yuchun, \& Wen, 2012; Ko, Niimura, \& Lee, 2003; Kouba, Menaa, Hasni, \& Boudour, 2015, 2016; Kumar \& Yadav, 2016; Lal, Barisal, \& Nayak, 2016; Mohanty, Patra, \& Ray, 2016; Nandar, 2008; Siddik, Vinayagam, \& Gopinath; Tan \& Zhang, 2011). Penelitian lain juga membahas bagaimana aplikasi metode cerdas yang dapat digunakan sebagai metode optimasi pada pembangkit wind-diesel, diantaranya (Hendrawan \& Al Riza, 2016; Zabidi, Tahir, Yassin, \& Rizman, 2017).

Dari beberapa penelitian sebelumnya, pengaturan frekuensi banyak menggunakan konvensional controller seperti Proportional, Integral, Derivative (PID). Namun dari hasil penelitian tersebut, penggunaan PID masih memerlukan studi lanjut terutama permasalahan penalaan parameter PID. Oleh krena itu, pada penelitian ini suatu metode kecerdasan buatan berbasis Diferential Evolution (DEVO) diusulkan sebagai metode penalaan parameter PID winddiesel. Metode DEVO adalah suatu algoritma yang terinspirasi dari teori evolusi, dan penerapannya sebagai teknik optimasi sudah banyak dilakukan.

\section{METODE PENELITIAN}

\subsection{Pre-Processing}

\section{Pemodelan Pembangkit Listrik Sistem Hibrid}

Sistem pembangkit listrik hibrid wind-diesel merupakan pembangkit listrik tenaga angin dan diesel, system ini dapat dipasang pada daerah terisolir seperti daerah pegunungan, yang dimana kecepatan angin di daerah tersebut berpotensi untuk menggerakkan turbin angin dan yang memproduksi listrik. Namun, pada suatu system yang kompleks yang terinterkoneksi, system ini menjadi tidak optimal. Output Wind-Diesel diharapkan hasil pembangkitannya dapat menyediakan ketersediaan energi yang baik bagi konsumen. Untuk mengoptimalkan kinerja wind-diesel, diperlukan tipe dan karakteristik kontrol pembangkitan yang baik. Perubahan frekuensi harus dijaga tetap stabil untuk mengoptimalkan kinerja peralatan. Beberapa cara atau strategi untuk menjaga stabilitas sistem termasuk mengurangi perbedaan generator dan beban, menyesuaikan deviasi frekuensi sistem, mengendalikan dengan beban buatan, mengalihkan prioritas pengendalian beban, menggunakan flywheels, Superconductor Magnetic Energy Storage (SMES) dan Penyimpanan Energi Baterai (BES). Beberapa masalah yang terjadi pada pembangkitan seperti stabilitas frekuensi kecil. Hal ini dapat disebabkan pengaturan gain yang tidak menguntungkan di Automatic Voltage Regulator (AVR), serta jumlah saluran transmisi panjang yang menghasilkan kemampuan transmisi yang lebih lemah (garis lemah).

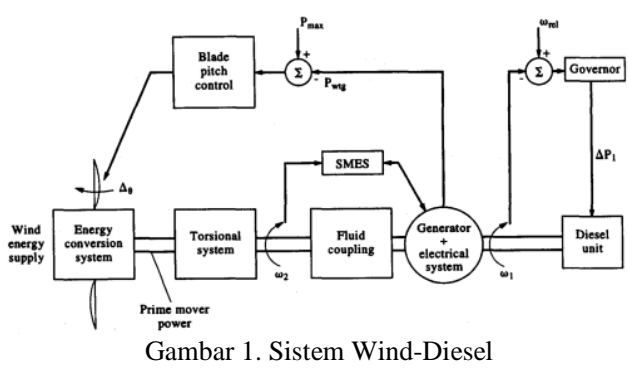

Metode penelitian dalam Model sistem turbin angin diilustrasikan pada gambar 1 di atas, dan pemodelan ditunjukkan pada Gambar berikut, diantaranya: blok wind turbine dan diesel, blok control dan blok dinamis generator. Berikut blok transfer function wind-diesel. 


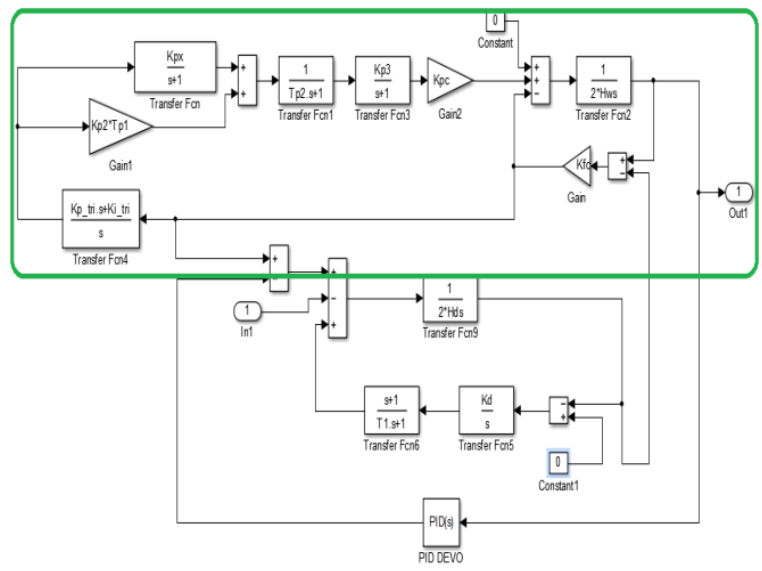

Gambar 2. Pemodelan Wind Turbine

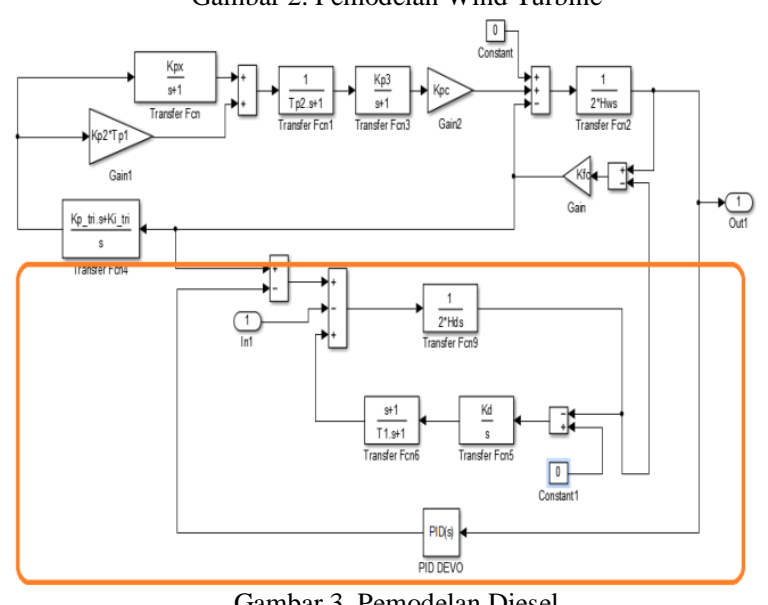

Gambar 3. Pemodelan Diesel

\subsection{Processing}

\section{Algoritma Differential Evolution}

Pada tahap processing, adigunakan algoritma cerdas untuk mengoptimasi pemodelan yang sudah dibuat ditahap sebelumnya. Penggunaan algoritma cerdas semakin berkembang dan menunjukkan hasil yang signifikan, seperti pada metode algoritma logika fuzzy (Fahmizal Fahmizal, 2018) dan neural network (Sucipto Sucipto, 2018). Dalam artificial intelligence, teori algoritma evolusi merupakan bagian dari komputasi evolusi. Algoritma evolusi pada awalnya mempertahankan struktur populasi, kemudian berkembang sesuai dengan aturan seleksi, mutasi rekombinasi dan kelangsungan hidup yang biasa disebut dengan operator genetik. Untuk menentukan kesehatan dan performa dari tiap individu yang ada di populasi, dibutuhkan sebuah lingkungan bersama. Individu yang paling cocok dengan lingkungan ini lebih mungkin untuk diseleksi sebagai individu - individu untuk bereproduksi atau bereplikasi. Lalu rekombinasi dan mutasi memodifikasi individu - individu ini untuk menghasilkan sebuah individ unggul. Algoritma evolusi bekerja dengan baik dalam mendekati solusi terhadap semua masalah karena algoritma ini tida membuat asumsi, dan juga ditunjukkan dari keberhasilan dalam bidang ekonomi, pemasaran, robotik, ilmu sosial, kimia, fisika dan politik.
Teknik dari algoritma evolusi diterapkan pada pemodelan evolusi biologi yang umumnya terbatas dalam melakukan eksplorasi terhadap proses evolusi mikro. Namun simulasi dari komputer Tierra dan Avida berusaha untuk memodelkan dinamika evolusi makro.Dalam penerapan paling nyata dari algoritma evolusi, kompleksitas adalah faktor penghalang. Bahkan, kekompleksitas-an komputasi adalah hasil dari fungsi kecocokan. Pendekatan kecocokan ini adalah salah satu cara untuk mengatasi kendala ini. Namun, kesederhanaan algoritma evolusi justru sering memecahkan masalah yang kompleks, bahkan kekompleksitas-an algoritma tidak terhubung secara langsung tehadap kekomplesitas-an masalah.

\section{Objective Function}

Fungsi objektif algoritma DEVO yang digunakan pada penelitian ini adalah meminimalkan Integral Time Absolut Error (ITAE).

$$
\text { ITAE }=\int_{0}^{t} t|\Delta \omega(t)| d t
$$

Berdasarkan objective function tersebut, parameter PID akan dicari oleh DEVO. Parameter tersebut antara lain $\mathrm{Kp}$, Ki dan $\mathrm{Kd}$. Untuk melihat kinerja masing-masing controller, maka analisis system dilakukan dengan beberapa model skema controller, yaitu untuk Wind-Diesel tanpa Kontrol, dengan PID-Trial, dan dengan PID-DEVO. Masing-masing pemodelan dan algoritma DEVO dibuat menggunakan Simulink Matlab 2013.

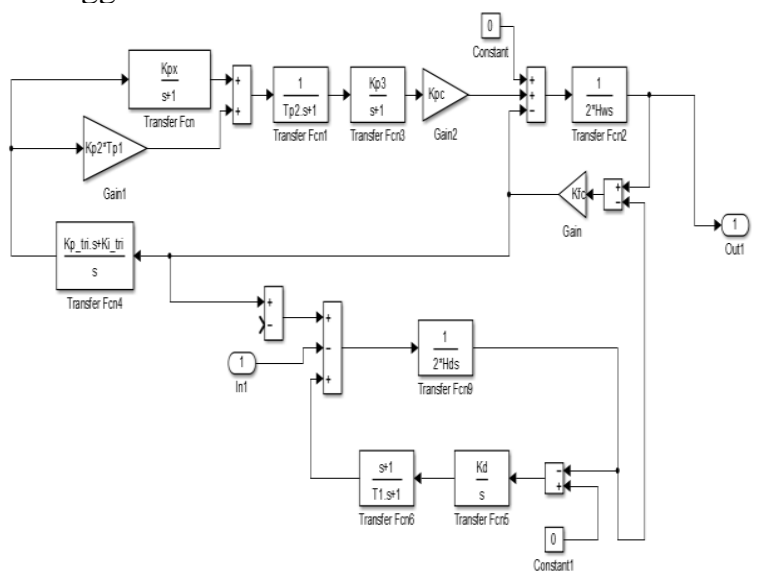

Gambar 4. Pemodelan Wind-Diesel Tanpa Kontrol 


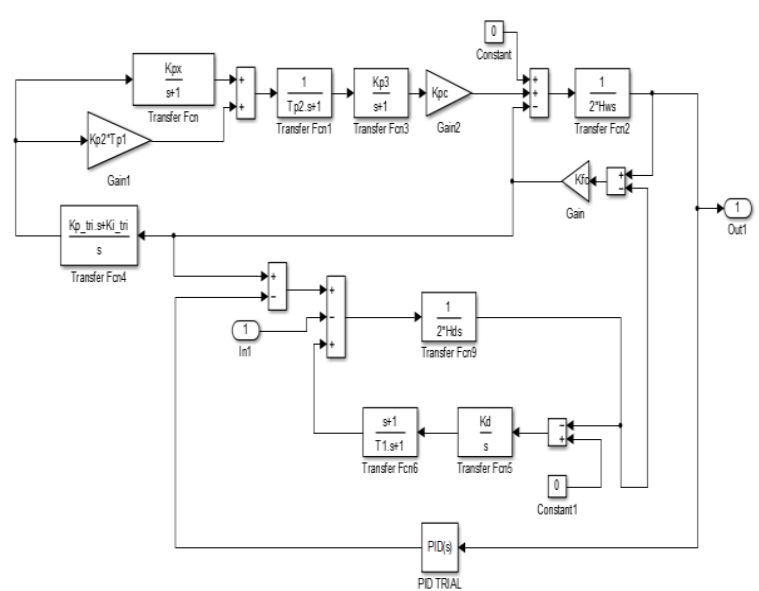

Gambar 5. Pemodelan Wind-Diesel PID Trial

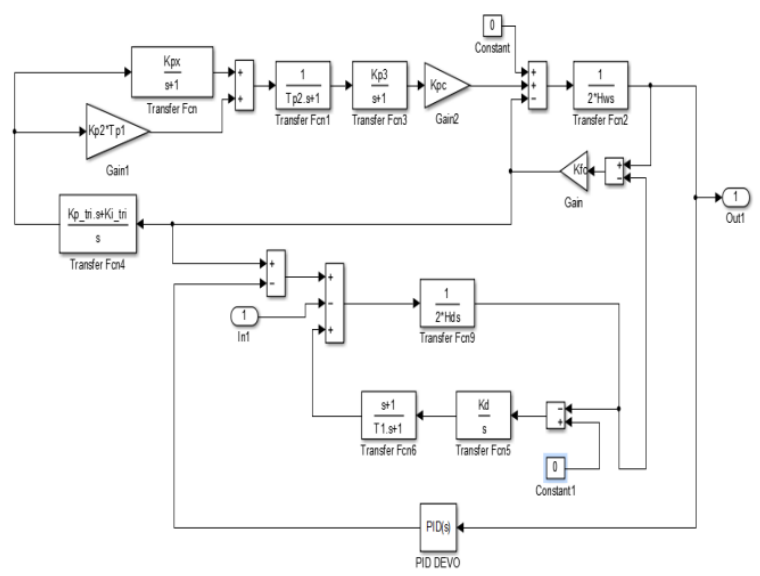

Gambar 6. Pemodelan Wind-Diesel PID-DEVO

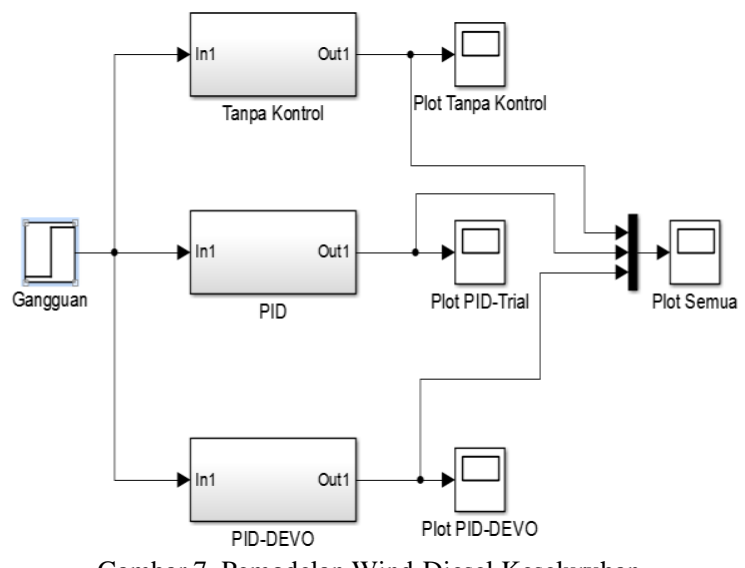

Gambar 7. Pemodelan Wind-Diesel Keseluruhan

Parameter algoritma DEVO ditampilkan sebagai berikut.

\begin{tabular}{cc} 
Tabel 1. Parameter DEVO & \\
\hline Parameter & Value \\
\hline Jumlah Parameter yang dioptimasi & 3 \\
Cross over & 0.8 \\
Jumlah Populasi & 30 \\
Strategi & 7 \\
Iterasi & 50 \\
\hline
\end{tabular}

\subsection{Processing}

Pada tahap processing hasil penalaan algoritma dibandingkan atau disesuaikan dengan fungsi tujuan yang sudah ditentukan. Berikut hasil optimasi PID dengan metode $D E V O$

Tabel 2. Hasil Optimasi PID dengan DEVO

Iteration: 50, Best: 0.000040, F: 0.700000, CR: 0.800000, NP

30

best $(1)=79.999917$

best $(2)=59.999826$

$\operatorname{best}(3)=9.900626$

iter $=51$

kp_devo $=79.9999$

ki_devo $=59.9998$

kd_devo $=9.9006$

Hasil optimasi DEVO didapatkan nilai fitness function sebesar 0.700000, dengan 50 iterasi.

Tabel 3. Hasil Penalaan Gain-PID

\begin{tabular}{cccc}
\hline \multirow{2}{*}{ Gain } & Lower & Limit & Hasil \\
& 80 & 90 & 79.9999 \\
$K p$ & 50 & 60 & 59.9998 \\
$K d$ & 10 & 15 & 9.9006 \\
\hline
\end{tabular}

\section{HASIL SIMULASI DAN ANALISIS}

\subsection{Tanpa Kontrol}

Simulasi pertama adalah simulasi open loop wind-diesel tanpa controller. Berikut ditunjukkan pada grafik hasil simulasi wind-diesel tanpa kontroler.

Gambar gambar 8 berikut menunjukkan grafik respon frekuensi Wind-Diesel open loop atau tanpa dilengkapi controller. Dari grafik di atas didapatkan nilai overshoot dan settling time Wind-Diesel yang sangat besar, seperti pada tabel berikut.

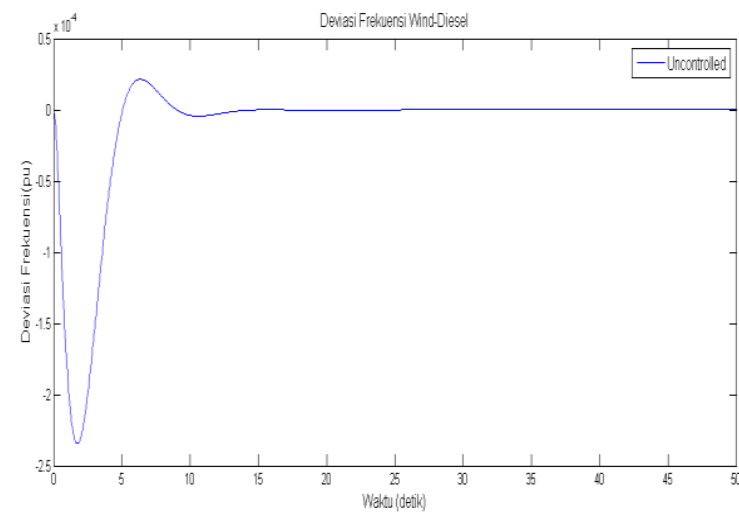

Gambar 8. Grafik frekuensi Wind-Diesel tanpa kontroler

Tabel 4. Respon overshoot dan settling time tanpa kontrol

\begin{tabular}{cc}
\hline Parameter & Nilai \\
\hline Overshoot $(p u)$ & $-0.0002344 \& 2.15 \mathrm{e}-05$ \\
Settling time $(s)$ & 13.2 \\
\hline
\end{tabular}

Nilai overshoot dan settling time yang dihasilkan dari simulasi pembangkit Wind-Diesel tanpa controller diatas merupakan nilai overshoot dan settling time yang paling besar diantara semua simulasi yang dilakukan, yaitu sebesar -0.0002344 hingga 2.15e-05 dengan settling time selama 13.2s. Hal ini disebabkan karena control frekuensi dari 
sistem hanya dilakukan atau dibebankan kepada governor saja, sehingga sistem yang tidak dilengkapi controller frekuensi pada generatornya ini menjadi sistem yang paling tidak stabil diantara sistem lain yang diberi controller.

\subsection{Kontrol PID Trial-Error}

Selanjutnya dengan menggunakan skema pengontrolan dengan PID yang ditunning secara coba-coba.

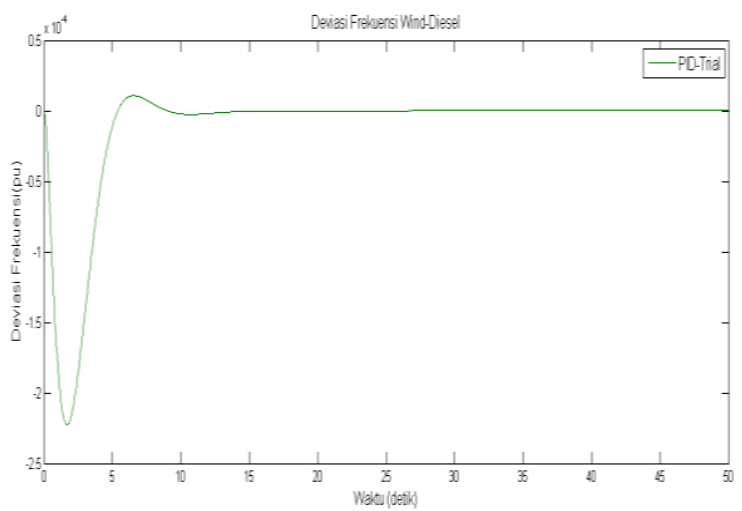

Gambar 9. Grafik frekuensi Wind-Diesel skema PID Trial Error

Grafik di atas memperlihatkan respon system dengan controller PID-Trial ketika ada gangguan pada system. Terlihat frekuensi mengalami overshoot sebelum kembali normal. Berikut hasil selengkapnya.

\begin{tabular}{cc} 
Tabel 5. Respon overshoot dan settling time PID-Trial Error \\
\hline Parameter & Nilai \\
\hline Overshoot $(\mathrm{pu})$ & $-0.0002227 \& 1.076 \mathrm{e}-05$ \\
Settling time $(\mathrm{s})$ & 12.8 \\
\hline
\end{tabular}

Tabel 5 menunjukkan respon overshoot system pada skema ini. Di mana dengan pemasangan controller PID yang ditunning secara Trial Error, kinerja wind-turbine belum optimal, osilasi frekuensi sistem sebesar $-0.0002227 \mathrm{pu}$ sampai $1.076 \mathrm{e}-05 \mathrm{pu}$. Settling time yang dibutuhkan adalah sebesar 12.8 detik untuk system kembali ke kondisi steady state.

\subsection{Kontrol PID-DEVO}

Skema control selanjutnya adalah skema pengontrolan yang diusulkan, yaitu dengan menggunakan kontroler PID yang dioptimasi dengan algoritma DEVO, dari simulasi didapatkan hasil pada gambar 10 berikut. Di mana menunjukkan respon frekuensi untuk sistem Wind-Diesel dengan kontrol PID-Devo. Hasil selenngkapnya pada tabel 6.

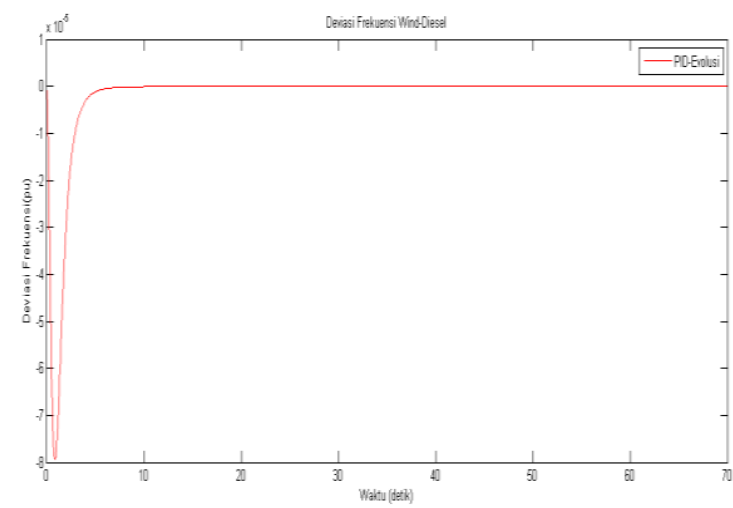

Gambar 10. Grafik frekuensi Wind-Diesel skema PID-DEVO

\begin{tabular}{cc} 
Tabel 6. Respon overshoot dan settling time PID-Devo \\
\hline Parameter & Nilai \\
\hline Overshoot $(p u)$ & $-7.932 \mathrm{e}-05 \& 6.792 \mathrm{e}-10$ \\
Settling time $(\mathrm{s})$ & 5,4 \\
\hline
\end{tabular}

Tabel 6 menunjukkan nilai overshoot pada skema controller PID-DEVO, sebesar -7.932e-05 sampai 6.792e-10. Dengan kata lain, pada skema ini ketika sistem mengalami suatu gangguan atau perubahan beban, maka frekuensi yang dihasilkan berisolasi turun yaitu sebesar -7.932e-05 pu, dan kemudian kembali ke kondisi steady state setelah setelah waktu di atas 5.4 detik lebih. Berikut ini perbandingan model untuk masing-masing skema pengontrolan.

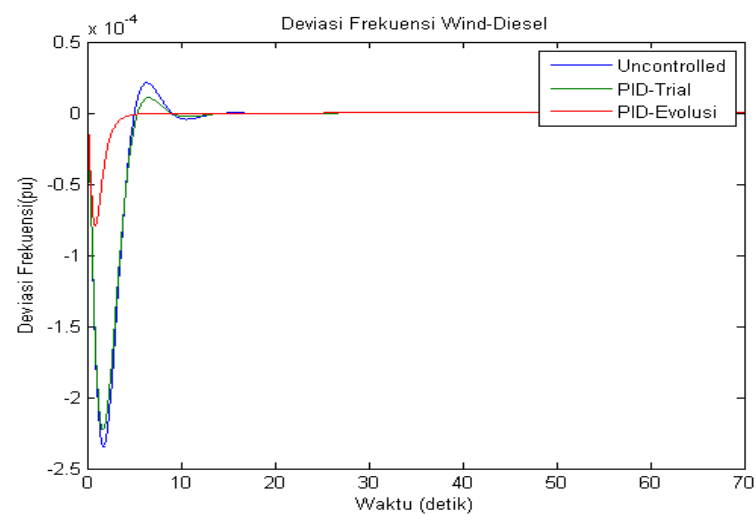

Gambar 11. Grafik perbandingan respon frekuensi semua skema kontroler

Gambar 11 menunjukkan perbandingan dari ketiga skema pengontrolan sistem pembangkit listrik tenaga hibrid turbin angin dan diesel, di mana untuk suatu pembangkit listrik hybrid ini direkomendasikan agar untuk meningkatkan kinerja system dilakukan dengan menambahkan controller yang dapat meredam fluktuasi ketika terjadi perubahan beban secara tiba-tiba. Dengan penalaan parameter yang optimal pada Controller PID ini akan menghasilkan kinerja yang signifikan dalam memberikan peredaman osilasi, oleh karena itu skema ini disarankan diterapkan untuk sistem pembangkit hibrid Wind-Diesel, di mana untuk metode penalaan controller dengan menggunakan metode cerdas berbasis Diferensial Evolusi. 


\section{KESIMPULAN}

Dengan menggunakan metode cerdas Diferensial Evolusi (DEVO) sebagai metode penalaan controller PID, didapatkan hasil penalaan parameter nilai $P I D$ yang optimal di mana, $K p=$ 79.9999, $K i=59.9998, K d=9.9006$.

Dengan menggunakan PID-DEVO pada sistem kontrol Load Frequency Control (LFC) yang dirancang, dapat memperbaiki respon frekuensi sebuah sistem Wind-Diesel. Hal ini ditunjukkan dengan nilai settling time sebesar 5.8 detik yang merupakan nilai settling time tercepat dan juga nilai overshoot sebesar -7.932e-05 hingga 6.792e-10 pu yang merupakan nilai overshoot terkecil dari model kontroler yang lain.

\section{DAFTAR PUSTAKA}

BHA'ITI, T., AL-ADEMI, A., \& BANSAL, N. Load Frequency Control Of Isolated Wind Diesel Hybrid Power Systems.

BHATTI, T., AL-ADEMI, A., \& BANSAL, N. (1997). Load frequency control of isolated wind diesel hybrid power systems. Energy conversion and management, 38(9), 829837.

FAHMIZAL FAHMIZAL, G. Y. D., DONNY BUDI PRATAMA, FAHMI FATHUDDIN, WINARSIH WINARSIH. (2018). Rancang Bangun Sistem Penstabil Kamera (Gimbal) dengan Logika Fuzzy untuk Pengambilan Gambar Foto dan Video. Jurnal Teknologi Informasi dan Ilmu Komputer (JTIIK), 5(3), 277-286. doi:http://dx.doi.org/10.25126/itiik.201853 785

HENDRAWAN, Y., \& AL RIZA, D. F. (2016). Machine Vision Optimization using Nature-Inspired Algorithms to Model Sunagoke Moss Water Status. International Journal on Advanced Science, Engineering and Information Technology, 6(1), 45-57.

JUNRUI, H., YUCHUN, H., \& WEN, T. (2012). Load frequency control of wind diesel hybrid power systems via predictive control. Paper presented at the Control Conference (CCC), 2012 31st Chinese.

KO, H., NIIMURA, T., \& LEE, K. (2003). An intelligent controller for a remote winddiesel power system-design and dynamic performance analysis. Paper presented at the Power Engineering Society General Meeting, 2003, IEEE.

KOUBA, N. E. Y., MENAA, M., HASNI, M., \& BOUDOUR, M. (2015). A novel robust automatic generation control in interconnected multi-area power system based on bat inspired algorithm. Paper presented at the Control, Engineering \&
Information Technology (CEIT), 2015 3rd International Conference on

KOUBA, N. E. Y., MENAA, M., HASNI, M., \& BOUDOUR, M. (2016). A novel optimal frequency control strategy for an isolated wind-diesel hybrid system with energy storage devices. Wind Engineering, 40(6), 497-517.

KUMAR, S., \& YADAV, G. D. (2016). Load Frequency Control in Wind-Diesel Based Isolated Power System by Pitch-Angle Controller.

LAL, D., BARISAL, A., \& NAYAK, S. (2016). Load frequency control of wind diesel hybrid power system using DE algorithm. Paper presented at the Intelligent Systems and Control (ISCO), 2016 10th International Conference on

MOHANTY, A., PATRA, S., \& RAY, P. K. (2016). Robust fuzzy-sliding mode based UPFC controller for transient stability analysis in autonomous wind-diesel-PV hybrid system. IET Generation, Transmission \& Distribution, 10(5), 1248-1257.

NANDAR, C. S. A. (2008). Parameter Optimization of Pitch Controller for Robust Frequency Control in an Isolated Wind-diesel Hybrid Power System Using Genetic Algorithm. TELKOMNIKA, 6(3), 145-154.

SIDDIK, S., VINAYAGAM, A. S., \& Gopinath, R. Load Frequency Control of a Hybrid Wind Diesel System Using Fuzzy Logic Control.

SUCIPTO SUCIPTO, R. W. U., DIMAS FIRMANDA AL-RIZA, SIMPING YULIATUN, SUPRIYANTO SUPRIYANTO, AGUS SUPRIATNA SOMANTRI. (2018). Pendugaan Rendemen Tebu Menggunakan Sifat Biolistrik dan ANN untuk Pengembangan Alat Ukur Cepat Rendemen Tebu. Jurnal Teknologi Informasi dan Ilmu Komputer (JTIIK), 5(3), 315-324. doi:http://dx.doi.org/10.25126/jtiik.201853 $\underline{635}$

TAN, W., \& ZHANG, J. (2011). Load frequency control for wind-diesel hybrid systems. Paper presented at the Control Conference (CCC), 2011 30th Chinese.

ZABIDI, A., TAHIR, N. M., YASSIN, I. M., \& RIZMAN, Z. I. (2017). The Performance of Binary Artificial Bee Colony (BABC) in Structure Selection of Polynomial NARX and NARMAX Models. International Journal on Advanced Science, Engineering and Information Technology, 7(2), 373379 . 